\title{
EKSPLORASI DAN IDENTIFIKASI GULMA, HIJAUAN PAKAN DAN LIMBAH PERTANIAN YANG DIMANFAATKAN SEBAGAI PAKAN TERNAK DI WILAYAH LAHAN KERING LOMBOK UTARA
}

\section{EXPLORATION AND IDENTIFICATION OF WEEDS, FORAGE AND AGRICULTURAL WASTES USED AS FODDER AT THE REGION OF NORTH LOMBOK DRY LAND}

\author{
Ni Made Laksmi Ernawati* dan I Ketut Ngawit \\ Fakultas Pertanian, Universitas Mataram, Mataram, 83126
}

Submitted: 4 December 2014, Accepted: 11 May 2015

\section{INTISARI}

Sulitnya mengatasi gulma dan kelangkaan pakan ternak pada waktu musim kemarau merupakan masalah utama di lahan kering. Tujuan penelitian ini adalah untuk mengeksplorasi dan mengidentifikas beberapa jenis gulma, hijauan, dan limbah pertanian yang dapat dimanfaatkan sebagai pakan ternak yang nantinya dapat diolah menjadi pakan ternak awetan silase dan hay. Penelitian eksploratif untuk mengidentifikasi, mengamati, dan mengumpulkan data telah dilakukan dengan metode deskriptif gulma dominan, hijauan, dan limbah pertanian yang umum dimanfaatkan oleh petani/peternak untuk pakan ternak. Pemanfaatan gulma, hijauan, dan limbah pertanian sebagai pakan ternak ditentukan berdasarkan tingkat kesukaan ternak sapi dan pengalaman empiris petani/peternak. Hasil eksplorasi dan identifikasi menunjukkan bahwa jenis gulma yang dominan ditemukan adalah jenis gulma berdaun lebar dengan dominansi $34,62-81,45 \%$ dan gulma berdaun sempit (rumput-rumputan dan teki) dengan dominansi 28,65-65,38\%. Gulma berdaun lebar yang umum digunakan sebagai pakan ternak di antaranya adalah: Cintella asiatica, Amaranthus spp., Mikania sp., Cyclosorous aridus, Gleichenia linearis, Physalis angulata, Portulaca oleracea, Mucaena pruriens dan Desmodium scalpe. Gulma rumput-rumputan dan teki potensial sebagai pakan ternak dengan tingkat kesukaan mencapai sangat disukai sampai amat sangat disukai ternak sapi. Forage dan limbah pertanian yang berpotensi dijadikan pakan ternak adalah daun gamal, daun sengon, daun dan pelepah pisang, daun kelapa, serta jerami kacang tanah, jagung dan ubi jalar.

(Kata kunci: Identifikasi dan eksplorasi, Hijauan pakan, Lahan kering, Limbah pertanian, Pakan ternak)

\section{ABSTRACT}

Difficulties on weeds control and fodder scarcity in dry season are the major problems at dry land. Aim of this research was to identify and to explore the potency of several kinds of weeds, forages, and agricultural wastes that can be used as fodder, and further might be processed to make hay and silage. Explorative research to identify, observe, and collect data has been done using descriptive method of dominant weeds, forages, and agricultural waste that frequently used as fodder by farmers. The farmer's decision to use weeds, forages, and agricultural wastes were determined by preference level of cattles and farmers empirical experiences. Result showed that dominant weeds found were broad leafed weeds with domination level 34.62-81.45\% and narrow leafed weeds (grasses and teki) with domination level 28.65-65.38\%. Broad leafed weeds that generally used as fodder were Cintella asiatica, Amaranthus spp., Mikania sp., Cyclosorous aridus, Gleichenia linearis, Physalis angulata, Portulaca oleracea, Mucaena pruriens, and Desmodium scalpe. Grasses weeds and teki were potential fodder with preference level of cattle from very much like to extremely like. Forage and agricultural waste that be potential as fodder were gamal leaf, sengon leaf, banana leaf and stem and coconut, agricultural waste of peanuts, corn, and sweet potato.

(Key words: Animal feed, Agricultural wastes, Dry land, Fodder, Forage, Identification and exploration, Weeds)

\footnotetext{
* Korespondensi (corresponding author):

Telp. +62 81310083392

E-mail: dr.laksmiernawati@yahoo.com
} 


\section{Pendahuluan}

Fungsi alih lahan pertanian yang subur menyebabkan petani/peternak berupaya mengembangkan dan meningkatkan produktivitas lahan kering. Lahan kering di luar kawasan hutan yang meliputi lahan pekarangan, tegalan, kebun, dan lain-lain ternyata mencapai luas $61,68 \%$ dari total keseluruhan 452.290 ha luas lahan di kawasan Lombok (Bappeda Tk. I Nusa Tenggara Barat, 2010). Ada beberapa kendala utama yang dijumpai dalam usaha mempertahankan kesinambungan sistem usahatani ekologis terpadu di lahan kering. Kendala tersebut adalah produktivitas tanah semakin berkurang akibat semakin menurunnya kadar bahan organik tanah, masalah gulma yang sulit dikendalikan, serta populasi ternak ruminansia yang tidak stabil (Wangiyana dan Ngawit, 2010; Ngawit dan Budianto, 2011).

Petani selain mengusahakan tanaman pangan juga biasanya memelihara ternak ruminansia. Pada waktu musim penghujan, tanaman pakan ternak tumbuh, sehingga tersedia secara melimpah. Sementara itu, pada musim kemarau, petani/peternak mengalami kesulitan dalam mendapatkan pakan ternak, sehingga terpaksa menjual ternaknya sebelum cukup umur/bobotnya. Hal ini mengakibatkan terjadinya penurunan populasi ternak yang signifikan pada musim kemarau (Ifar dan Bambang, 2002; Ernawati et al., 2012).

Gulma merupakan salah satu unsur pengganggu tanaman yang tumbuhnya tidak dikehendaki pada setiap pengusahaan tanaman. Dalam usaha pengembangan sistem usahatani ekologis terpadu di lahan kering, masalah gulma masih menjadi kendala yang sulit diatasi. Hampir sepertiga bagian dari total biaya produksi untuk pengusahaan setiap tanaman dipergunakan untuk mengendalikan gulma (Ngawit et al., 2008; Wangiyana dan Ngawit, 2010). Sulitnya gulma dikendalikan di wilayah lahan kering Lombok Utara dibandingkan pada tanah-tanah subur yang telah dikelola secara intensif, disebabkan karena gulma sudah beradaptasi dan mantap pada kondisi lahan tersebut sehingga secara fisiologis mampu bersaing lebih kuat dibandingkan dengan tanaman budidaya dalam mendapatkan unsur hara, air, ruang tumbuh, dan sinar matahari (Zimdahl, 1990).
Pemanfaatan gulma sebagai pakan ternak masih terbatas pada jenis-jenis gulma tertentu. Di wilayah Lombok Utara, gulma dimanfaatkan sebagai pakan ternak terbatas dalam bentuk segar dan diberikan secara langsung. Dengan kata lain belum ada upaya untuk mengolahnya menjadi bahan pakan ternak yang lebih berkualitas. Asih (2004) menyatakan bahwa petani/peternak kecil yang memelihara sapi Bali mengutamakan pakannya dari gulma jenis rumput-rumputan, limbah pertanian dan produk hijauan lainnya (forage) secara turun temurun, tanpa penerapan manajemen pengelolaan pakan dan pemeliharaan yang baik. Pada saat musim hujan atau saat produk hijauan berlimpah takaran pakan yang diberikan menjadi tidak terkontrol. Namun pada saat musim kemarau, para petani/peternak hanya memberikan ternaknya dengan takaran pakan yang seadanya, tanpa memperhitungkan kandungan zat-zat nutrisi terutama karbohidrat, protein, mineral, dan vitamin.

Istilah forage menunjuk pada bagian tanaman yang dapat dimakan oleh ternak (edible parts of plants) dengan cara digembalakan (grazing) atau dipanen sebagai pakan (zero grazing). Dalam hal ini biji dari tanaman dimaksud tidak termasuk dalam pengertian forage (Odach, 2011). Pengertian limbah pertanian adalah sisa-sisa tanaman pertanian setelah dipanen atau diambil bagian utamanya (Anonim, 2012).

Petani sering membuang percuma atau membakar gulma, limbah pertanian, dan produk hijauan lainnya pada waktu musim hujan atau sebelum pengolahan tanah dan sesaat setelah panen. Hal ini terjadi karena petani tidak memiliki pengetahuan untuk pengolahannya atau desain pemanfaatannya yang bersifat multiguna, seperti untuk pakan ternak awetan silase dan hay (Ngawit, 2007; Ngawit, 2008). Sebelum petani diberikan pengetahuan tentang desain pemanfaatannya, maka perlu diperkenalkan gulma selain rumput-rumputan yang dapat dimanfaatkan sebagai pakan ternak maupun forage dan limbah pertanian yang kemungkinan akan disukai ternak.

Penelitian ini bertujuan untuk mengeksplorasi dan mengidentifikasi beberapa jenis gulma, hijauan lainnya, dan limbah pertanian yang dapat dimanfaatkan sebagai pakan ternak. Dengan ditemukannya bahanbahan yang berpotensi sebagai pakan ternak maka akan dapat diolah lebih lanjut menjadi pakan ternak awetan silase dan hay. 
Pengolahan pakan ini diharapkan dapat meningkatkan ketersediaan pakan ternak yang berkualitas secara berkesinambungan. Kelimpahannya tidak saja pada musim hujan atau saat ada tanaman tetapi tersedia saat musim kemarau.

\section{Materi dan Metode}

Pengamatan jenis gulma dominan, hijauan, dan limbah pertanian dilakukan di dua lokasi yaitu: di kawasan Desa Celelos Kecamatan Tanjung, Lombok Utara dan kawasan Desa Mumbul Sari dan Akar-akar, Kecamatan Bayan, Lombok Utara. Sampel pengamatan ditentukan sebanyak 5 titik areal pada setiap tipe agroekosistem lahan yang diamati. Metode pengamatan menggunakan metode "Kuadrat Sensus". Jumlah dan luas petak sampel pengamatan ditentukan berdasarkan metode "Kurve Area terhadap Keragaman Jenis" (Species area curve), sedangkan distribusi petak sampel pengamatan menggunakan metode sampling beraturan (Ngawit, 2005). Jenis-jenis gulma diidentifikasi berdasarkan Backer dan Bakhuizen Van Den Brink (1968) dan Wirjahardja dan Dekker (1987). Peubah yang diamati adalah: kerapatan nisbi, frekuensi nisbi, dan dominansi nisbi dari masingmasing spesies gulma/vegetasi. Untuk mengetahui jenis gulma/vegetasi yang paling dominan dilakukan analisis Some Dominance Ratio (SDR). Indeks keragaman vegetasi antara dua kawasan dihitung dengan menggunakan persamaan menurut Shannon-Wieever (Pielou, 1975 cit. Soejono dan Isniningsih, 1990). Untuk mengetahui pengaruh perbedaan tingkat pengelolaan (kesuburan) lahan terhadap gulma/vegetasi penutup tanah, maka vegetasi di setiap kawasan dibandingkan dengan menghitung koefisien kesamaan komunitas (C) menurut metode Kulezynski (Oosting, 1956 cit. Soejono dan Isniningsih, 1990; Ngawit, 2005).

Identifikasi gulma, bahan hijauan lainnya, dan limbah pertanian yang umum dijadikan pakan ternak oleh petani/peternak dilakukan dengan metode deskriptif dengan teknik wawancara langsung terhadap petani responden yang penetapannya ditentukan secara purposive sampling. Selain berdasarkan pengalaman secara empiris, penentuan juga didasarkan atas tingkat kesukaan sapi terhadap gulma, hijauan lainnya, dan limbah pertanian sebagai pakannya. Tingkat kesukaan ternak sapi ini ditentukan dengan nilai skor, penentuan nilai skor tersebut berdasarkan jumlah/persentase gulma, hijauan, dan limbah pertanian yang dimakan. Nilai skor dan tingkat kesukaan ternak sapi terhadap pakan yang disediakan disajikan pada Tabel 1 (Bergen dan Bates, 1994).

\section{Hasil dan Pembahasan}

Hasil pengamatan di Desa Celelos didapatkan gulma dominan adalah jenis berdaun lebar yang mencapai komposisi lebih dari 20 jenis dengan dominansi $81,45 \%$, sedangkan kelompok gulma berdaun sempit (rumput-rumputan dan teki) komposisinya hanya mencapai 10 jenis dengan dominansi 28,64\% (Tabel 2). Pada Tabel 2 tampak bahwa gulma Ageratum houstonianum (dengan SDR 10,61\%), Tridax procumbens (dengan SDR 10,46\%), dan Cyclosorous aridus (dengan SDR 10,43\%) merupakan jenis yang dominan. Beberapa gulma yang ditemukan cukup dominan adalah Ocxalis corniculata (kacang-kacangan), Mikinia micrantha, Mikania cordata, Ageratum conyzoides, Cintella asiatica, Clidemia hirta,

Tabel 1. Nilai skor dan tingkat kesukaan ternak sapi terhadap pakan hijauan (score value and preference level of beef cattles on forage)

\begin{tabular}{ccl}
\hline \hline $\begin{array}{c}\text { Nilai skor } \\
\text { (score value) }\end{array}$ & \multicolumn{1}{c}{$\begin{array}{c}\text { Persentase hijauan yang dimakan } \\
\text { (percentage of forage consumed (\%)) }\end{array}$} & $\begin{array}{c}\text { Tingkat kesukaan ternak } \\
\text { (preference level of beef cattles) }\end{array}$ \\
\hline 8 & $90-100 \%$ hijauan dimakan (90-100\% forage consumed) & $\begin{array}{l}\text { Amat sangat suka (extremely like) } \\
7\end{array}$ \\
6 & $70-90 \%$ hijauan dimakan (80-90\% forage consumed) & Sangat suka (very much like) \\
5 & $60-70 \%$ hijauan dimakan (70-80\% forage consumed) & Suka sekali (very like) \\
4 & $60-50 \%$ hijauan dimakan (60-70\% forage consumed) & Suka (like) \\
3 & $50-40 \%$ hijauan dimakan (50-40\% forage consumed) & Cukup suka (quite like) \\
2 & $40-30 \%$ hijauan dimakan (40-30\% forage consumed) & Tidak suka (dislike) \\
1 & $<30 \%$ hijauan dimakan (<30\% forage consumed) & Sangat tidak suka (extremely \\
& & dislike)
\end{tabular}

Sumber: Bergen dan Bates (1994). 
Tabel 2. Gulma dominan berdasarkan nilai SDR di wilayah pengamatan desa Celelos (dominant weeds based on SDR value in Celelos village observation region)

\begin{tabular}{|c|c|c|c|c|c|c|}
\hline \multirow[t]{2}{*}{ Jenis gulma (kinds of weeds) } & \multicolumn{5}{|c|}{$\begin{array}{l}\text { Nilai SDR (\%) pada setiap titik sampel area pengamatan } \\
\text { (SDR value (\%) at each spot of observation area) }\end{array}$} & \multirow{2}{*}{$\begin{array}{c}\text { Rata-rata } \\
\text { (mean) }\end{array}$} \\
\hline & Ap1 & Ap 2 & Ap3 & Ap4 & Ap5 & \\
\hline \multicolumn{7}{|c|}{ Rumput-rumputan dan teki (grasses and teki) } \\
\hline Axonopus compressus & 13,66 & 1,34 & 14,46 & 12,43 & 12,45 & 10,66 \\
\hline Cynodon dactylon & 8,78 & 1,21 & 1,80 & 1,22 & 1,34 & 2,87 \\
\hline Panicum repens & 7,32 & 1,66 & 1,88 & 1,24 & 1,36 & 2,69 \\
\hline Imperata cylindrica & 7,34 & 3,22 & 0,66 & 0,21 & 0,11 & 2,30 \\
\hline Paspalum conjugatum & 2,32 & 2,20 & 3,56 & 2,12 & 1,22 & 2,28 \\
\hline Commelina diffusa & 6,61 & 0,45 & 0,76 & 1,02 & 0,43 & 1,85 \\
\hline Pogonatherum paniceum & 2,32 & 1,48 & 1,44 & 1,22 & 2,21 & 1,73 \\
\hline Themeda gigantea & 3,34 & 1,33 & 0,55 & 1,04 & 1,36 & 1,54 \\
\hline Sorghum halepense & 4,32 & 1,41 & 0,21 & 1,11 & 0,28 & 1,50 \\
\hline Paspalum distichum & 1,44 & 3,51 & 0,15 & 0,06 & 0,13 & 1,01 \\
\hline Ceperus sp. & 0,30 & 0,41 & 0,10 & 0,05 & 0,10 & 0,18 \\
\hline \multicolumn{7}{|c|}{ Gulma berdaun lebar (broad leaf weeds) } \\
\hline Ageratum houstonianum & 6,11 & 12,74 & 10,23 & 11,67 & 12,32 & 10,61 \\
\hline Tridax procumbens & 6,54 & 13,66 & 12,22 & 12,43 & 11,45 & 10,46 \\
\hline Cyclosorous aridus & 3,32 & 3,24 & 15,38 & 15,11 & 15,10 & 10,43 \\
\hline Okxalis corniculata & 1,32 & 10,45 & 10,22 & 11,28 & 11,10 & 8,87 \\
\hline Mikinia micrantha & 4,56 & 6,22 & 8,22 & 9,23 & 9,33 & 7,51 \\
\hline Mikania cordata & 3,88 & 7,64 & 7,78 & 8,22 & 8,43 & 7,19 \\
\hline Ageratum conyzoides & 3,45 & 7,18 & 2,30 & 2,21 & 2,43 & 3,51 \\
\hline Cintella asiatica & 0,45 & 0,22 & 3,66 & 3,56 & 3,66 & 2,31 \\
\hline Clidemia hirta & 1,44 & 4,55 & 4,22 & 0,34 & 0,02 & 2,11 \\
\hline Gleichenia linearis & 0,67 & 4,10 & 1,00 & 1,34 & 1,42 & 1,75 \\
\hline Chromolaena odorata & 2,10 & 4,10 & 0,12 & 0,12 & 0,04 & 1,29 \\
\hline Loranthus spp. & 1,34 & 1,44 & 1,23 & 0,01 & 1,12 & 0,97 \\
\hline Artemisia vulgaris & 2,22 & 1,15 & 0,34 & 0,12 & 0,45 & 0,85 \\
\hline Erechtites valerianifolia & 1,26 & 2,33 & 0,01 & 0,02 & 0,01 & 0,72 \\
\hline Drymoglossuma sp. & 0,40 & 0,40 & 1,40 & 1,10 & 0,19 & 0,69 \\
\hline Borreria alata & 0,45 & 0,89 & 0,66 & 0,34 & 0,66 & 0,60 \\
\hline Melastoma candidum & 1,25 & 1,43 & 0,10 & 0,10 & 0,11 & 0,59 \\
\hline Lantana camara & 0,03 & 2,01 & 0,01 & 0,01 & 0,02 & 0,41 \\
\hline Thitonia diversifolia & 0,02 & 0,02 & 0,32 & 1,04 & 0,12 & 0,30 \\
\hline Galinsoga ciliata & 0,88 & 0,01 & 0,01 & 0,01 & 0,01 & 0,18 \\
\hline Plantogo mayor & 0,56 & 0,01 & 0,01 & 0,02 & 0,02 & 0,12 \\
\hline
\end{tabular}

Gleichenia linearis, Chromolaena odorata, Loranthus spp., Artemisia vulgaris, Erechtites valerianifolia, Drymoglossuma pilaselloides (pipisan), Borreria alata, dan Melastoma candidum.

Kelompok gulma rumput-rumputan yang dominan di lokasi penelitian ini hanya satu jenis yaitu jenis rumput pahitan (Axonopus compressus) dengan nilai SDR $10,66 \%$. Disusul oleh jenis rumput-rumputan lainnya yang cukup dominan dan populasinya merata seperti Cynodon dactylon, Panicum repens, Imperata cylindrica, Paspalum conjugatum, Commelina diffusa, Pogonatherum paniceum, Themeda gigantea, Sorghum halepense, dan Paspalum distichum dengan nilai SDR ratarata antara 2,87-1,01\%. Khusus jenis gulma Sorghum halepense (rumput gelagah) dan Themeda gigantea (gelagak) cukup dominan pada areal yang terbuka di lokasi pengamatan Celelos Bawah, pada gelengan atau pembatas kebun petani serta di pematang dan tepi jalan. Karena dominansinya cukup mencolok dan tahan kekeringan, perlu diuji lebih lanjut untuk diolah potensinya sebagai pakan ternak awetan.

Lantai tegakan wilayah pengamatan sampel di Desa Celelos agak tertutup oleh beberapa lapis tajuk yang tersusun oleh pohon, perdu, belukar, dan vegetasi bawah terbuka serta vegetasi naungan. Akibatnya intensitas cahaya yang sampai ke lantai tegakan menjadi lebih rendah. Sekalipun demikian intensitas cahaya yang cukup rendah ini juga merupakan akibat dari keadaan lapis tajuk di beberapa sampel didominansi oleh tegakan pohon-pohon besar. Keadaan ini berakibat terhadap komposisi jenis tumbuhan bawah yang ada di lokasi penelitian yang didominansi oleh 
gulma berdaun lebar dan sebagian kecil dari jenis gulma rumput-rumputan. Hal ini karena rumput-rumputan lebih toleran daerah terbuka dengan intensitas cahaya penuh, sedangkan gulma berdaun lebar lebih toleran terhadap lingkungan yang lebih tertutup. Memperhatikan keadaan vegetasi di wilayah pengamatan Desa Celelos, terdapat kecenderungan komposisi jenis gulma yang tertutup vegetasi pohon dan belta lebih kaya dari areal terbuka.

Populasi tegakan pohon di atas tajuk jenis gulma-gulma tersebut, pada kebun petani cukup dominan beberapa hijauan (forage) yang umumnya dimanfaatkan sebagai tanaman peneduh atau pelindung serta sebagai sumber pendapatan petani seperti sengon, mahoni, bajur, dedap, lamtoro, gamal, dan pisang serta beberapa jenis tanaman buah-buahan tahunan seperti nangka, durian, salak dan pisang. Tampak pula bahwa pada areal pengamatan yang terletak di wilayah Celelos Atas dengan keadaan iklim lebih basah dibandingkan dengan Celelos Bawah beberapa gulma dominan cukup khas seperti dari kelompok pakis Cyclosorous aridus, dan sembung rambat, seperti: Mikania cordata dan Mikinia micrantha.

Hal sebaliknya terjadi pada wilayah pengamatan di Desa Mumbul Sari dan Akarakar (Tabel 3). Pada lokasi ini di bawah tegakan didominansi oleh jenis rumputrumputan dan teki meskipun komposisinya hanya mencapai 13 jenis namun dominansinya mencapai $65,38 \%$ sementara gulma berdaun lebar meskipun komposisi jenisnya lebih banyak hanya mampu menutupi di bawah tegakan $34,62 \%$. Jenis rumput-rumputan yang paling dominan adalah Eleusine indica, Digitaria sanguinalis, dan cyperus rotundus dengan nilai SDR masing-masing $11,02,10,62$, dan $10,83 \%$. Disusul oleh beberapa jenis yang dominan seperti Imperata cylindrica, Paspalum conjugatum, Paspalum distichum, Cynodon dactylon, Panicum repens, dan Sorghum halepense dengan nilai SDR rata-rata antara $3,30-5,68 \%$. Beberapa jenis yang cukup dominan seperti Axonopus compressus, Commelina diffusa, Echinochloa colonum, dan Pogonatherum paniceum, dengan nlai SDR rata-rata antara $0,53-1,65 \%$. Kelompok berdaun lebar hanya beberapa jenis yang dominan seperti Tridax procumbens, Physalis angulata, Portulaca oleracea, dan Cyclosorous aridus dengan nilai SDR masing-masing 7,38, 5,51, 5,19, dan 3,81\%. Beberapa yang cukup dominan seperti Okxalis corniculata, Cintella asiatica, Mikania cordata, Mikinia micrantha, Clidemia hirta, Gleichenia linearis, Borreria alata, Amaranthus sp, Ageratum conyzoides, dan Ageratum houstonianum dengan nilai SDR antara 1,09-2,30\%. Secara keseluruhan di dua wilayah penelitian terdapat 25 jenis gulma rumput-rumputan dan teki dari kelompok suku Acanthaceae, Poaceae, Violaceae, dan Cyperaceae namun di wilayah Desa Mumbul Sari dan Akar-akar ditemukan pula beberapa jenis dari kelompok suku Themeda dan Heteropogon.

Bila dikaji dari segi fungsinya sebagai padang penggembalaan alternatif dan sebagai sumber forage bahan pakan ternak, di kedua wilayah penelitian memperlihatkan mutu yang rendah terutama di wilayah pengamatan Desa Celelos. Kelompok tumbuhan yang didominansi dari suku Acanthaceae dan Violaceae tidak umum digunakan sebagai pakan ternak demikian pula banyak jenis-jenis yang lainnya yang ditemukan dominan. Berdasarkan data hasil pengamatan (Tabel 4 dan 5), kelompok yang umum digunakan sebagai pakan ternak adalah Poaceae, Fabaceae, Salviniaceae, dan di wilayah pengamatan Mumbul Sari dan Akar-akar kadang-kadang kelompok Cyperaceae. Di wilayah pengamatan Desa Celelos dominasi rumput-rumputan (Poaceae) sebagai sumber pakan utama agak rendah, karenanya produktivitas forage segar juga akan rendah.

Gulma berdaun lebar yang mendominansi wilayah penelitian Desa Celelos, selain hanya beberapa jenis yang dimanfaatkan sebagai pakan ternyata juga lebih banyak jenis yang tidak disukai ternak sehingga kurang bermutu sebagai pakan. Selain gulma rumput-rumputan, gulma berdaun lebar terutama dari suku Fabaceae ikut menentukan mutu suatu padang penggembalaan atau sumber forage. Padang pengembalaan atau sumber forage yang baik menghasilkan pakan yang tersusun dari rumput (Poaceae) dan legume (Fabaceae) dengan perbandingan 6,5:3,5 (Purbajanti, 2013). Jadi jelas jenis dan produktivitas legume sebagai sumber protein pakan di kedua wilayah penelitian tidak memadai. Legume yang ditemukan hanya ada dua jenis dari legume liar dan merambat yang termasuk jenis Desmodium scalpe dan Mucaena pruriens. Produktivitas kedua jenis 
Tabel 3. Gulma dominan berdasarkan nilai SDR di wilayah pengamatan desa Mumbul Sari dan Akar-Akar (dominant weeds based on SDR value in Mumbul Sari and Akar-Akar village observation region)

\begin{tabular}{|c|c|c|c|c|c|c|}
\hline \multirow[t]{2}{*}{ Jenis gulma (kinds of weeds) } & \multicolumn{5}{|c|}{$\begin{array}{c}\text { Nilai SDR (\%) pada setiap titik sampel area pengamatan } \\
\text { (SDR value (\%) at each spot of observation area) }\end{array}$} & \multirow{2}{*}{$\begin{array}{l}\text { Rata- } \\
\text { rata } \\
\text { (mean) }\end{array}$} \\
\hline & Ap1 & Ap 2 & Ap3 & Ap4 & Ap5 & \\
\hline \multicolumn{7}{|c|}{ Gulma rumput-rumputan dan teki (grasses weeds and teki) } \\
\hline Eleusine indica & 11,01 & 10,44 & 10,12 & 12,23 & 11,32 & 11,02 \\
\hline Digitaria sanguinalis & 10,32 & 9,13 & 10,62 & 12,82 & 10,23 & 10,62 \\
\hline Cynodon dactylon & 6,34 & 6,12 & 6,66 & 6,21 & 3,11 & 5,68 \\
\hline Paspalum conjugatum & 4,11 & 4,74 & 5,23 & 5,67 & 4,32 & 4,81 \\
\hline Paspalum distichum & 5,78 & 3,21 & 3,80 & 4,22 & 5,34 & 4,47 \\
\hline Panicum repens & 4,54 & 4,66 & 4,22 & 4,43 & 3,45 & 4,26 \\
\hline Imperata cylindrica & 5,12 & 4,66 & 4,88 & 4,24 & 2,36 & 4,25 \\
\hline Sorghum halepense & 3,52 & 3,41 & 3,21 & 3,11 & 3,28 & 3,30 \\
\hline Commelina diffusa & 1,61 & 1,45 & 1,76 & 2,02 & 1,43 & 1,65 \\
\hline Echinochloa colonum & 2,56 & 1,45 & 1,12 & 1,06 & 0,36 & 1,31 \\
\hline Axonopus compressus & 1,66 & 1,34 & 1,46 & 1,43 & 0,45 & 1,26 \\
\hline Pogonatherum paniceum & 1,32 & 0,48 & 0,44 & 0,22 & 0,21 & 0,53 \\
\hline Themeda gigantea & 0,44 & 0,33 & 0,55 & 0,04 & 0,36 & 0,34 \\
\hline Cyperus rotundus & 9,45 & 10,66 & 11,21 & 11,66 & 12,22 & 10,83 \\
\hline \multicolumn{7}{|c|}{ Gulma berdaun lebar (broad leaf weeds) } \\
\hline Tridax procumbens & 1,32 & 3,00 & 10,22 & 11,28 & 11,10 & 7,38 \\
\hline Physalis angulata & 2,56 & 4,22 & 6,22 & 7,23 & 7,33 & 5,51 \\
\hline Portulaca oleracea & 1,88 & 5,64 & 5,78 & 6,22 & 6,43 & 5,19 \\
\hline Cyclosorous aridus & 3,32 & 3,24 & 5,30 & 4,11 & 3,10 & 3,81 \\
\hline Okxalis corniculata & 2,30 & 2,38 & 3,56 & 2,12 & 1,22 & 2,31 \\
\hline Mikania cordata & 2,12 & 2,00 & 2,42 & 2,55 & 2,01 & 2,22 \\
\hline Cintella asiatica & 0,45 & 0,22 & 3,66 & 3,35 & 3,66 & 2,26 \\
\hline Clidemia hirta & 1,44 & 4,55 & 4,22 & 0,34 & 0,02 & 2,11 \\
\hline Mikinia micrantha & 2,32 & 2,12 & 2,06 & 2,03 & 2,00 & 2,10 \\
\hline Ageratum conyzoides & 1,45 & 5,18 & 0,30 & 0,21 & 0,43 & 1,51 \\
\hline Gleichenia linearis & 0,60 & 2,90 & 1,22 & 1,34 & 1,42 & 1,49 \\
\hline Amaranthus sp. & 2,10 & 4,10 & 0,12 & 0,12 & 0,04 & 1,29 \\
\hline Ageratumhoustonianum & 1,44 & 3,91 & 0,25 & 0,11 & 0,23 & 1,18 \\
\hline Borreria alata & 1,00 & 1,04 & 1,12 & 1,32 & 1,00 & 1,09 \\
\hline Phyllanthus niruri & 2,22 & 1,15 & 0,34 & 0,12 & 0,45 & 0,85 \\
\hline Erechtites valerianifolia & 1,26 & 2,33 & 0,01 & 0,02 & 0,01 & 0,72 \\
\hline Mimosa pudica & 1,02 & 1,11 & 0,87 & 0,16 & 0,14 & 0,66 \\
\hline Mucaena pruriens & 0,45 & 0,89 & 0,66 & 0,34 & 0,66 & 0,60 \\
\hline Melastoma candidum & 1,25 & 1,43 & 0,10 & 0,10 & 0,11 & 0,59 \\
\hline Thitonia diversifolia & 0,02 & 0,02 & 0,32 & 1,04 & 0,12 & 0,30 \\
\hline Desmodium scalpe & 0,00 & 0,00 & 0,00 & 1,10 & 0,00 & 0,22 \\
\hline Galinsoga ciliata & 0,88 & 0,01 & 0,01 & 0,01 & 0,01 & 0,18 \\
\hline Plantogo mayor & 0,56 & 0,01 & 0,01 & 0,02 & 0,02 & 0,12 \\
\hline Artemisia vulgaris & 0,07 & 0,06 & 0,10 & 0,02 & 0,01 & 0,05 \\
\hline Euphorbia hirta & 0,08 & 0,04 & 0,03 & 0,01 & 0,01 & 0,03 \\
\hline Chromolaena odorata & 0,08 & 0,02 & 0,02 & 0,01 & 0,01 & 0,02 \\
\hline Lantana camara & 0,03 & 0,01 & 0,01 & 0,01 & 0,02 & 0,01 \\
\hline Loranthus spp. & 0,00 & 0,00 & 0,00 & 0,01 & 0,00 & 0,00 \\
\hline
\end{tabular}

legume ini sebagai forage yang dapat diduga dari nilai SDR-nya masih sangat rendah yaitu hanya 0,60 dan $0,22 \%$. Kedua jenis legume ini selain kurang produktif juga tidak termasuk jenis bermutu sebagai pakan ternak sumber protein. Ini berarti bahwa dari sejumlah kurang lebih 42 jenis gulma dan forage yang ditemukan di wilayah penelitian, gulma berdaun lebar hanya 3 jenis dari kelompok suku Salviniaceae dan Fabaceae yang berpotensi sebagai pakan ternak namun dominansinya tidak potensial.
Sebaliknya lebih dari 20 jenis di antaranya berpotensi sebagai gulma dominan disetiap areal pertanaman maupun di padang penggembalaan. Hijauan (forage) lainnya seperti daun gamal, lamtoro, santen, nangka, pisang dan kelapa yang potensinya cukup tinggi sebagai sumber pakan, ternyata kurang dimanfaatkan oleh petani/peternak di lokasi penelitian. Hal ini karena beberapa jenis hijauan tersebut kategorinya hanya termasuk kurang disukai sampai dengan cukup disukai oleh ternak sapi. Selain itu 
Tabel 4. Gulma dominan dan hijauan lainnya (forage) yang dimanfaatkan sebagai pakan ternak dan tingkat kesukaan ternak sapi di wilayah desa Celelos

(dominant weeds and other forages that used as fodder and preference level of beef cattle in Celelos village region)

\begin{tabular}{|c|c|c|c|}
\hline $\begin{array}{l}\text { Jenis gulma dan forage } \\
\text { lainnya (kinds of weeds and } \\
\text { other forage) }\end{array}$ & $\begin{array}{c}\text { Pemanfaatan secara } \\
\text { empiris (utilization } \\
\text { empirically) }\end{array}$ & $\begin{array}{l}\text { Bobot pakan yg } \\
\text { termakan (\%) } \\
\text { (weight of fodder } \\
\text { consumed (\%)) }\end{array}$ & $\begin{array}{c}\text { Kategori tingkat kesukaan } \\
\text { ternak terhadap pakan } \\
\text { (category of preference } \\
\text { level of beef cattle on } \\
\text { fodder) }\end{array}$ \\
\hline \multicolumn{4}{|c|}{ Gulma jenis rumput-rumputan (grasses weeds) } \\
\hline Axonopus compressus & $\begin{array}{l}\text { Selalu dimanfaatkan } \\
\text { (frequently utilized) }\end{array}$ & 89,24 & $\begin{array}{l}\text { Sangat disukai } \\
\text { (very much like) }\end{array}$ \\
\hline Paspalum conjugatum & $\begin{array}{l}\text { Selalu dimanfaatkan } \\
\text { (frequently utilized) }\end{array}$ & 98,64 & $\begin{array}{l}\text { Amat sangat disukai } \\
\text { (extremely like) }\end{array}$ \\
\hline Paspalum distichum & $\begin{array}{l}\text { Selalu dimanfaatkan } \\
\text { (frequently utilized) }\end{array}$ & 96,78 & $\begin{array}{l}\text { Amat sangat disukai } \\
\text { (extremely like) }\end{array}$ \\
\hline Cynodon dactylon & $\begin{array}{l}\text { Selalu dimanfaatkan } \\
\text { (frequently utilized) }\end{array}$ & 92,32 & $\begin{array}{l}\text { Amat sangat disukai } \\
\text { (extremely like) }\end{array}$ \\
\hline Panicum repens & $\begin{array}{l}\text { Selalu dimanfaatkan } \\
\text { (frequently utilized) }\end{array}$ & 88,81 & $\begin{array}{l}\text { Sangat disukai } \\
\text { (very much like) }\end{array}$ \\
\hline Imperata cylindrica & $\begin{array}{l}\text { Kurang dimanfaatkan } \\
\text { (less utilized) }\end{array}$ & 46,78 & $\begin{array}{l}\text { Kurang disukai } \\
\text { (less like) }\end{array}$ \\
\hline Commelina diffusa & $\begin{array}{l}\text { Kurang dimanfaatkan } \\
\text { (less utilized) }\end{array}$ & 50,00 & $\begin{array}{l}\text { Kurang disukai } \\
\text { (less like) }\end{array}$ \\
\hline Pogonatherum paniceum & $\begin{array}{l}\text { Kurang dimanfaatkan } \\
\text { (less utilized) }\end{array}$ & 40,35 & $\begin{array}{l}\text { Kurang disukai } \\
\text { (less like) }\end{array}$ \\
\hline Sorghum halepense & $\begin{array}{l}\text { Kurang dimanfaatkan } \\
\text { (less utilized) }\end{array}$ & 58,27 & $\begin{array}{l}\text { Cukup disukai } \\
\text { (like) }\end{array}$ \\
\hline Themeda gigantea & $\begin{array}{l}\text { Kurang dimanfaatkan } \\
\text { (less utilized) }\end{array}$ & 60,12 & $\begin{array}{l}\text { Cukup disukai } \\
\text { (like) }\end{array}$ \\
\hline Ceperus rotundhus & $\begin{array}{l}\text { Cukup dimanfaatkan } \\
\text { (mild utilized) }\end{array}$ & 55,56 & $\begin{array}{l}\text { Cukup disukai } \\
\text { (like) }\end{array}$ \\
\hline \multicolumn{4}{|c|}{ Gulma berdaun lebar (broad leaf weeds) } \\
\hline Cyclosorous aridus & Dimanfaatkan (utilized) & 90,04 & $\begin{array}{l}\text { Sangat disukai } \\
\text { (very much like) }\end{array}$ \\
\hline Tridax procumbens & $\begin{array}{l}\text { Tidak dimanfaatkan } \\
\text { (no utilized) }\end{array}$ & 8,12 & $\begin{array}{l}\text { Sangat tidak disukai } \\
\text { (extremely dislike) }\end{array}$ \\
\hline Mikania cordata & $\begin{array}{l}\text { Cukup dimanfaatkan } \\
\text { (mild utilized) }\end{array}$ & 48,28 & $\begin{array}{l}\text { Kurang disukai } \\
\text { (less like) }\end{array}$ \\
\hline Mikinia micrantha & $\begin{array}{l}\text { Tidak dimanfaatkan } \\
\text { (no utilized) }\end{array}$ & 7,24 & $\begin{array}{l}\text { Sangat tidak disukai } \\
\text { (extremely dislike) }\end{array}$ \\
\hline Clidemia hirta & $\begin{array}{l}\text { Tidak dimanfaatkan } \\
\text { (no utilized) }\end{array}$ & 6,23 & $\begin{array}{l}\text { Sangat tidak disukai } \\
\text { (extremely dislike) }\end{array}$ \\
\hline Ocxalis corniculata & $\begin{array}{l}\text { Cukup dimanfaatkan } \\
\text { (mild utilized) }\end{array}$ & 60,02 & Cukup disukai (like) \\
\hline Gleichenia linearis & $\begin{array}{l}\text { Cukup dimanfaatkan } \\
\text { (mild utilized) }\end{array}$ & 39,78 & Kurang (less like) \\
\hline Pogonatherum paniceum & Dimanfaatkan (utilized) & 90,01 & $\begin{array}{l}\text { Sangat disukai } \\
\text { (very much like) }\end{array}$ \\
\hline Cintella asiatica & $\begin{array}{l}\text { Tidak dimanfaatkan } \\
\text { (no utilized) }\end{array}$ & 35,18 & $\begin{array}{l}\text { Kurang disukai } \\
\text { (less like) }\end{array}$ \\
\hline Ageratum conyzoides & $\begin{array}{l}\text { Tidak dimanfaatkan } \\
\text { (no utilized) }\end{array}$ & 27,14 & $\begin{array}{l}\text { Tidak disukai } \\
\text { (dislike) }\end{array}$ \\
\hline Ageratum houstonianum & Dimanfaatkan (utilized) & 78,52 & Disukai (like) \\
\hline \multicolumn{4}{|c|}{ Hijauan lainnya dan limbah pertanian (forage and agricultural waste) } \\
\hline Danun gamal (gamal leaf) & Dimanfaatkan (utilized) & 65,73 & Cukup disukai (like) \\
\hline $\begin{array}{l}\text { Daun lamtoro (Leucaena } \\
\text { glauca leaf) }\end{array}$ & $\begin{array}{l}\text { Cukup dimanfaatkan } \\
\text { (mild utilized) }\end{array}$ & 36,44 & $\begin{array}{l}\text { Kurang disukai } \\
\text { (less like) }\end{array}$ \\
\hline $\begin{array}{l}\text { Daun dadap (Erythrina } \\
\text { spp.) }\end{array}$ & $\begin{array}{l}\text { Cukup dimanfaatkan } \\
\text { (mild utilized) }\end{array}$ & 60,15 & Cukup disukai (like) \\
\hline $\begin{array}{l}\text { Daun nangka (jackfruit } \\
\text { leaf) }\end{array}$ & $\begin{array}{l}\text { Cukup dimanfaatkan } \\
\text { (mild utilized) }\end{array}$ & 34,78 & $\begin{array}{l}\text { Kurang disukai } \\
\text { (less like) }\end{array}$ \\
\hline Daun sengon (sengon leaf) & Dimanfaatkan (utilized) & 87,87 & $\begin{array}{l}\text { Sangat disukai } \\
\text { (very much like) }\end{array}$ \\
\hline
\end{tabular}


Lanjutan Tabel 4.

\begin{tabular}{|c|c|c|c|}
\hline $\begin{array}{l}\text { Jenis gulma dan forage } \\
\text { lainnya (kinds of weeds and } \\
\text { other forage) }\end{array}$ & $\begin{array}{l}\text { Pemanfaatan secara } \\
\text { empiris (utilization } \\
\text { empirically) }\end{array}$ & $\begin{array}{l}\text { Bobot pakan yg } \\
\text { termakan }(\%) \\
\text { (weight of fodder } \\
\text { consumed (\%)) }\end{array}$ & $\begin{array}{c}\text { Kategori tingkat kesukaan } \\
\text { ternak terhadap pakan } \\
\text { (category of preference } \\
\text { level of beef cattle on } \\
\text { fodder) }\end{array}$ \\
\hline $\begin{array}{l}\text { Batang dan daun ubi jalar } \\
\text { (stem and leaf of sweet } \\
\text { potato) }\end{array}$ & $\begin{array}{l}\text { Cukup dimanfaatkan } \\
\text { (mild utilized) }\end{array}$ & 76,72 & Disukai (like) \\
\hline $\begin{array}{l}\text { Pelepah dan daun pisang, } \\
\text { kelapa dan limbah lainnya } \\
\text { (stem and leaf of banana, } \\
\text { coconut and other waste) }\end{array}$ & Dimanfaatkan (utilized) & 90,04 & $\begin{array}{l}\text { Sangat disukai } \\
\text { (very much like) }\end{array}$ \\
\hline
\end{tabular}

Tabel 5. Gulma dominan dan hijuan lainnya (forage) yang dimanfaatkan sebagai pakan ternak dan tingkat kesukaan ternak sapi di wilayah Desa Mumbul Sari dan Akar-akar

(dominant weeds and other forages used as fodder and preference level of beef cattles in Mumbul Sari and Akar-Akar village region)

\begin{tabular}{|c|c|c|c|}
\hline $\begin{array}{l}\text { Jenis gulma dan forage } \\
\text { lainnya (kinds of weeds and } \\
\text { other forage) }\end{array}$ & $\begin{array}{l}\text { Pemanfaatan } \\
\text { secara empiris } \\
\text { (utilize empirically) }\end{array}$ & $\begin{array}{l}\text { Bobot pakan yang } \\
\text { termakan }(\%)(\text { weight of } \\
\text { fodder consumed (\%)) }\end{array}$ & $\begin{array}{l}\text { Kategori tingkat kesukaan } \\
\text { ternak terhadap pakan } \\
\text { (category of preference level } \\
\text { of beef cattles on fodder) }\end{array}$ \\
\hline \multicolumn{4}{|c|}{ Gulma jenis rumput-rumputan (grasses weeds) } \\
\hline Digitaria sanguinalis & $\begin{array}{l}\text { Selalu dimanfaatkan } \\
\text { (frequently utilized) }\end{array}$ & 98,73 & $\begin{array}{l}\text { Amat sangat disukai } \\
\text { (extremely like) }\end{array}$ \\
\hline Eleusine indica & $\begin{array}{l}\text { Selalu dimanfaatkan } \\
\text { (frequently utilized) }\end{array}$ & 96,23 & $\begin{array}{l}\text { Amat sangat disukai } \\
\text { (extremely like) }\end{array}$ \\
\hline Paspalum conjugatum & $\begin{array}{l}\text { Selalu dimanfaatkan } \\
\text { (frequently utilized) }\end{array}$ & 97,26 & $\begin{array}{l}\text { Amat sangat disukai } \\
\text { (extremely like) }\end{array}$ \\
\hline Paspalum distichum & $\begin{array}{l}\text { Selalu dimanfaatkan } \\
\text { (frequently utilized) }\end{array}$ & 96,21 & $\begin{array}{l}\text { Amat sangat disukai } \\
\text { (extremely like) }\end{array}$ \\
\hline Cynodon dactylon & $\begin{array}{l}\text { Selalu dimanfaatkan } \\
\text { (frequently utilized) }\end{array}$ & 98,33 & $\begin{array}{l}\text { Amat sangat disukai } \\
\text { (extremely like) }\end{array}$ \\
\hline Panicum repens & $\begin{array}{l}\text { Selalu dimanfaatkan } \\
\text { (frequently utilized) }\end{array}$ & 89,81 & $\begin{array}{l}\text { Sangat disukai } \\
\text { (very much like) }\end{array}$ \\
\hline Axonopus compressus & $\begin{array}{l}\text { Selalu dimanfaatkan } \\
\text { (frequently utilized) }\end{array}$ & 90,00 & $\begin{array}{l}\text { Sangat disukai } \\
\text { (very much like) }\end{array}$ \\
\hline Echinochloa colonum & $\begin{array}{l}\text { Selalu dimanfaatkan } \\
\text { (frequently utilized) }\end{array}$ & 98,13 & $\begin{array}{l}\text { Amat sangat disukai } \\
\text { (extremely like) }\end{array}$ \\
\hline Imperata cylindrica & Dimanfaatkan (utilized) & 43,18 & Kurang disukai (less like) \\
\hline Commelina diffusa & Dimanfaatkan (utilized) & 50,00 & Kurang disukai (less like) \\
\hline Pogonatherum paniceum & $\begin{array}{l}\text { Kurang dimanfaatkan } \\
\text { (less utilized) }\end{array}$ & 40,35 & Kurang disukai (less like) \\
\hline Sorghum halepense & $\begin{array}{l}\text { Kurang dimanfatkan } \\
\text { (less utilized) }\end{array}$ & 78,29 & Disukai sekali (very like) \\
\hline Themeda gigantea & $\begin{array}{l}\text { Kurang dimanfaatkan } \\
\text { (less utilized) }\end{array}$ & 80,41 & Disukai sekali (very like) \\
\hline Ceperus rotundhs & Dimanfaatkan (utilized) & 60,46 & Cukup disukai (like) \\
\hline \multicolumn{4}{|c|}{ Gulma berdaun lebar (broad leaf weeds) } \\
\hline Physalis angulata & $\begin{array}{l}\text { Kurang dimanfaatkan } \\
\text { (less utilized) }\end{array}$ & 59,33 & Cukup disukai (like) \\
\hline Portulaca oleracea & $\begin{array}{l}\text { Kurang dimanfaatkan } \\
\text { (less utilized) }\end{array}$ & 45,35 & Cukup disukai (like) \\
\hline Cyclosorous aridus & Dimanfaatkan (utilized) & 90,04 & $\begin{array}{l}\text { Sangat disukai } \\
\text { (very much like) }\end{array}$ \\
\hline Tridax procumbens & $\begin{array}{l}\text { Tidak dimanfaatkan } \\
\text { (no utilized) }\end{array}$ & 8,12 & $\begin{array}{l}\text { Sangat tidak disukai } \\
\text { (extremely dislike) }\end{array}$ \\
\hline Okxalis corniculata & $\begin{array}{l}\text { Tidak dimanfaatkan } \\
\text { (no utilized) }\end{array}$ & 6,78 & $\begin{array}{l}\text { Sangat tidak disukai } \\
\text { (extremely dislike) }\end{array}$ \\
\hline Mikania cordata & Dimanfaatkan (utilized) & 60,21 & Cukup disukai (like) \\
\hline Mikania micrantha & Dimanfaatkan (utilized) & 61,23 & Cukup disukai (like) \\
\hline Clidemia hirta & $\begin{array}{l}\text { Tidak dimanfaatkan } \\
\text { (no utilized) }\end{array}$ & 7,24 & $\begin{array}{l}\text { Sangat tidak disukai } \\
\text { (extremely dislike) }\end{array}$ \\
\hline
\end{tabular}


Lanjutan Tabel 5.

\begin{tabular}{|c|c|c|c|}
\hline $\begin{array}{c}\text { Jenis gulma dan forage } \\
\text { lainnya (kinds of weeds and } \\
\text { other forage) }\end{array}$ & $\begin{array}{l}\text { Pemanfaatan } \\
\text { secara empiris te } \\
\text { (utilize empirically) }\end{array}$ & $\begin{array}{l}\text { Bobot pakan yang } \\
\text { termakan }(\%) \text { (weight of } \\
\text { fodder consumed }(\%))\end{array}$ & $\begin{array}{l}\text { Kategori tingkat kesukaan } \\
\text { ternak terhadap pakan } \\
\text { (category of preference level } \\
\text { of beef cattles on fodder) }\end{array}$ \\
\hline Borreria alata & $\begin{array}{l}\text { Tidak dimanfaatkan } \\
\text { (no utilized) }\end{array}$ & 5,26 & $\begin{array}{l}\text { Sangat tidak disukai } \\
\text { (extremely dislike) }\end{array}$ \\
\hline Amaranthus spp. & $\begin{array}{l}\text { Kurang dimanfaatkan } \\
\text { (less utilized) }\end{array}$ & 72,45 & Disukai (like) \\
\hline Cintella asiatica & Dimanfaatkan (utilized) & 89,79 & $\begin{array}{l}\text { Sangat disukai } \\
\text { (very much like) }\end{array}$ \\
\hline Ageratum conyzoides & $\begin{array}{l}\text { Tidak dimanfaatkan } \\
\text { (no utilized) }\end{array}$ & 31,45 & Kurang disukai (less like) \\
\hline Ageratum houstonianum & $\begin{array}{l}\text { Tidak dimanfaatkan } \\
\text { (no utilized) }\end{array}$ & 24,76 & Tidak disukai (dislike) \\
\hline \multicolumn{4}{|c|}{ Hijauan lainnya dan limbah pertanian (forage and agricultural waste) } \\
\hline Daun gamal (gamal leaf) & Dimanfaatkan (utilized) & 79,63 & Disukai (like) \\
\hline $\begin{array}{l}\text { Daun lamtoro (Leucaena } \\
\text { glauca leaf) }\end{array}$ & Dimanfaatkan (utilized) & 60,75 & Cukup disukai (like) \\
\hline Daun santen (santen leaf) & $\begin{array}{l}\text { Cukup dimanfaatkan } \\
\text { (mild utilized) }\end{array}$ & 34,67 & Kurang disukai (less like) \\
\hline Daun nangka (jackfruit leaf) & $\begin{array}{l}\text { Cukup dimanfaatkan } \\
\text { (mild utilized) }\end{array}$ & 60,00 & Cukup disukai (like) \\
\hline Daun sengon (sengon leaf) & $\begin{array}{l}\text { Cukup dimanfaatkan } \\
\text { (mild utilized) }\end{array}$ & 34,78 & Kurang disukai (less like) \\
\hline $\begin{array}{l}\text { Pelepah dan daun pisang, } \\
\text { kelapa dan limbah lainnya } \\
\text { (banana stem and leaf, } \\
\text { coconut and other waste) }\end{array}$ & $\begin{array}{l}\text { Cukup dimanfaatkan } \\
\text { (mild utilized) }\end{array}$ & 78,76 & Disukai (like) \\
\hline $\begin{array}{l}\text { Batang, daun dan kelobot } \\
\text { jagung (stem, leaf and husk } \\
\text { corn) }\end{array}$ & Dimanfaatkan (utilized) & 99,67 & $\begin{array}{l}\text { Amat sangat disukai } \\
\text { (extremely like) }\end{array}$ \\
\hline $\begin{array}{l}\text { Batang, daun, dan kulit } \\
\text { kacang tanah (stem, leaf } \\
\text { and nutshell of peanuts) }\end{array}$ & Dimanfaatkan (utilized) & 92.76 & $\begin{array}{l}\text { Amat sangat disukai } \\
\text { (extremely like) }\end{array}$ \\
\hline $\begin{array}{l}\text { Batang dan daun ubi jalar } \\
\text { (stem and leaf of sweet } \\
\text { potato) }\end{array}$ & Dimanfaatkan (utilized) & 91,57 & $\begin{array}{l}\text { Amat sangat disukai } \\
\text { (extremely like) }\end{array}$ \\
\hline $\begin{array}{l}\text { Batang, daun dan limbah } \\
\text { sayuran semusim (stem,leat } \\
\text { and annual vegetable } \\
\text { waste })^{1}\end{array}$ & $\begin{array}{l}\text { Cukup dimanfaatkan } \\
\text { (mild utilized) }\end{array}$ & 58,98 & Cukup disukai (like) \\
\hline $\begin{array}{l}\text { Batang, daun dan limbah } \\
\text { buah-buahan semusim } \\
(\text { stem, leaf, and annual fruit } \\
\text { waste })^{2)}\end{array}$ & $\begin{array}{l}\text { Kurang dimanfaatkan } \\
\text { (less utilized) }\end{array}$ & 31,76 & Kurang disukai (less like) \\
\hline
\end{tabular}

kebiasaan petani/peternak di lokasi penelitian yang mengutamakan rumput-rumputan sebagai sumber pakan. Limbah pertanian seperti daun dan pelepah pisang, limbah jagung, limbah kacang tanah dan sayursayuran serta buah-buahan semusim telah dimanfaatkan namun masih terbatas sebagai pakan tambahan bila ketersediaan rumputrumputan terbatas waktu musim kemarau. Beberapa limbah pertanian tersebut termasuk dalam kategori sangat disukai ternak dan hanya limbah sayuran dan buah semusim yang kategorinya kurang disukai sampai cukup disukai.

\section{Kesimpulan}

Jenis gulma yang dominan ditemukan adalah jenis berdaun lebar dengan dominansi $34,62-81,45 \%$ dan gulma berdaun sempit (rumput-rumputan dan teki) dengan dominansi 28,64-65,38\%. Gulma berdaun lebar yang umum digunakan sebagai pakan ternak antara lain: Cintella asiatica, Amaranthus spp., Mikania sp., Cyclosorous 
aridus, Gleichenia linearis, Physalis angulata, Portulaca oleracea, Mucaena pruriens, dan Desmodium scalpe. Gulma rumput-rumputan dan teki potensial sebagai pakan ternak dengan tingkat kesukaan mencapai sangat disukai sampai amat sangat disukai ternak sapi. Forage dan limbah pertanian yang berpotensi dijadikan pakan ternak adalah daun gamal, daun sengon, daun dan pelepah pisang serta kelapa, limbah kacang tanah dan jagung serta ubi jalar.

\section{Ucapan Terima Kasih}

Tim penulis mengucapkan terima kasih kepada Direktorat Penelitian dan Pengabdian kepada Masyarakat Direktorat Jenderal Pendidikan Tinggi Kementrian Pendidikan dan Kebudayaan atas dana penelitian yang diberikan melalui MP3El.

\section{Daftar Pustaka}

Anonim. 2012. Pengertian Limbah Pertanian. http://spoilerin.blogspot.com/2012/03/p engertian-limbah-pertanian.html. Diakses pada 10 Februari 2015.

Asih, A. R. S. 2004. Manajemen Pemeliharaan Ternak. Fakultas Peternakan, Universitas Mataram. Mataram.

Backer, C. A. and R. C. Bakhuizen Van Den Brink Jr. 1968. Flora of Java. Vol. 1, 2 and 3. Wolters-Noordhoff N. V., Groningen, The Netherlands.

Bappeda Tk.I NTB. 2010. Data Pokok Pembangunan Propinsi Nusa Tenggara Barat. Kerjasama Bappeda Tk. I NTB dengan Kantor Wilayah Badan Pertanahan Nasional (BPN) Propinsi NTB.

Bergen, W. G. and D. B. Bates. 1994. Inophore polyeter: the effect on production efficiency and mode of action. J. Anim. Sci. 58: 1565-1583.

Ernawati, N. M. L., I. K. Ngawit, N. Farida, dan I. N. Sadia. 2012. Pengelolaan gulma, produk hijauan dan limbah pertanian sebagai pakan ternak awetan silase dan hay serta pemanfaatan seresah in-situnya untuk pupuk organik pada sistem usahatani ekologis terpadu di lahan kering. Laporan Hasil Penelitian Penprinas MP3EI 2011-2025 Fokus/Koridor Bali dan Nusa Tenggara, DP3M, Direktorat Jenderal Pendidikan Tinggi, Jakarta.
Ifar, S. dan A. N. Bambang. 2002. Potensi dan prospek usaha peternakan sapi potong di kawasan timur Indonesia (KTI) dalam kerangka pengembangan kawasan ekonomi terpadu (KAPET). Semiloka Strategi Pengembangan KAPET di Kawasan Timur Indonesia dalam Menghadapi Era Global, 5-6 Juli, Universitas Brawijaya.

Ngawit, I. K. 2005. Pengaruh periode bebas gulma dan kerapatan populasi tanaman terhadap daya kompetisi tanaman jagung varietas Pioneer di lahan kering. Agroteksos. V II: 103110.

Ngawit, I. K. 2007. Efikasi beberapa jenis herbisida terhadap tanaman penutup tanah leguminosa di jalur tanaman kopi muda. Agroteksos. 17: 104-113.

Ngawit, I. K. 2008. Efek periode bebas gulma dan kerapatan populasi tanaman terhadap daya kompetisasi tanaman jagung pada asosiasi dengan gulma. Jurnal IImiah Budidaya Pertanian I: 5359.

Ngawit, I. K. dan A. Budianto. 2011. Uji kemempanan beberapa jenis herbisida terhadap gulma pada tanaman kacang tanah dan dampaknya terhadap pertumbuhan dan aktivitas bakteri Rhizobium di dalam tanah. Jurnal IImiah Budidaya Pertanian 4: 27-36.

Ngawit, I. K., I. G. M. Kusnarta, A. Rohyadi, dan Wuryantoro. 2008. Rancang bangun usahatani ekologis terpadu yang bertumpu pada pengelolaan sumberdaya lahan berkelanjutan pada tiga tipe agroekosistem lahan kering di Pulau Lombok. Makalah Seminar Hasil Penelitian Hibah Bersaing Tahun II. DP3M, Direktorat Jenderal Pendidikan Tinggi, Jakarta.

Odach, R. 2011. List of Forage Legumes; Forage Grasses and Legumes; Forage Manure. http://www.hort.purdue.edu/ newcrop/cropmap/indiana/default.html. Accessed 11 Juni 2011.

Purbajanti, E. D. 2013. Rumput dan Legum sebagai Hijauan Makanan Ternak. Penerbit Graha llmu, Yogyakarta.

Soejono, E. A. dan S. Isniningsih. 1990. Komunitas tumbuhan bawah di antara tanaman koleksi pada tingkat pemeliharaan yang berbeda di cabang kebun raya Purwodadi. Prosiding I, Konferensi X, Himpunan IImu Gulma Indonesia, Malang, 13-15 Maret 1990. 
Wangiyana, W. dan I. K. Ngawit. 2010. Pengelolaan lahan kering berbasis penerapan model rancang bangun usahatani ekologis terpadu guna meningkatkan kesejahteraan masyarakat di kawasan pengembangan lahan kering Lombok Utara. Makalah Seminar Penerapan Ipteks pada Masyarakat. DP3M, Direktorat Jenderal Pendidikan Tinggi, Jakarta.
Wirjahardja S. and R. J. Dekker. 1987. The Weeds: Description, Ecology and Control. In: Weeds of Rice in Indonesia. M. Soerjani, Kostermans, A. J. G. H. and G. Tjitrosoepomo (eds). Published by Balai Pustaka, Jakarta.

Zimdahl. 1990. Weed Crop Competition. $4^{\text {th }}$ edn. A Review IPPC University of Oregon. Corvalis, Oregon. 